\title{
The Innovation of College and University Performance Management in Big Data Era
}

Pei Tian

Xi'an Peihua University, Xi'an, Shannxi, 710125, China

Keywords: Big data; Colleges and universities; Performance management; Innovation

\begin{abstract}
The traditional human resource management mode and working methods cannot be applied in the information era. The huge amount of data information and its continuous updating require a strong ability of dealing with and analyzing data in human resources professionals of colleges and universities. Big data will inevitably lead to a series of changes and challenges in human resource management, and accelerate the thinking reform of big data. Based on the author's learning and practical experience, this paper first interpreted the concept and characteristics of big data, and then analyzed big data's thinking on the performance management of college and university teachers. Finally, the paper put forward the innovative path of teacher performance management in universities based on big data.
\end{abstract}

\section{Introduction}

They are gradually enter the big data era from teachers' teaching to students' learning, from resource construction to work management and from school education to lifelong learning. As an important force in higher education, the performance management of college and university teachers' teaching and scientific research is an effective guarantee of the quality of education, but there are many problems and shortcomings in the performance management of college and university teachers. The appearance of big data provides new ideas and methods for this work. Based on this, this study started with the current situation and problems of teachers' performance management in colleges and universities, and drew lessons from the concept of big data. Moreover, it analyzed the inspiration of big data's thinking to the performance management of college and university teachers, and expounded the preparatory work that should be done to implement the performance management of teachers based on big data in colleges and universities in the future.

\section{The Concept and Characteristics of Big Data}

At present, the academia and the industry define the definition of big data from different point of views. As far as big data's definition is concerned, the more authoritative view is that Wikipedia argues that big data, or huge amount of information, means that it is impossible to crawl content with conventional software tools in allowed time. And the collection of data is managed and processed. McKinsey defines big data as a data set that is larger than conventional database tools to capture, store, manage, and analyze. He stressed in particular that it was not to say that a data set above a specific TB value was required to be big data. Gartner, a research information organization, argues that "big data" is an information assets that requires a new processing model to have greater decision-making power, insight and process optimization capabilities. With high growth rate and diversified information. The practice and application of big data in various industries has gradually influenced people's daily work and life style and knowledge system, and has produced new methods and new thinking concepts of thinking and solving problems, namely, the big data thinking. Fundamentally speaking, it is the profound embodiment of big data's internal logic. In recent years, more and more scholars apply big data thinking to various industries, such as economic management, manufacturing, agriculture, commerce, finance, transportation, film and television production, health care, sports and so on. It provides new ideas, methods and even new fields for the development of the industry. At present, the application of big data's thinking in education is 
mainly in university library, student information management, personnel file management and so on.

\section{The Inspiration of Big Data's Thinking to the Performance Management of College and University Teachers}

\subsection{Elaborate evaluation indicator system design and data acquisition}

Compared with the traditional indicator design and data collection of college teachers' performance management and with the support of big data, the indicator design and data collection can be more elaborate. In the teaching evaluation indicators, we can add more process evaluation indicators for data collection, such as teachers' attendance rate being more accurate to whether teachers are late, leaving early and the teacher teaching time, teacher-student interaction times and so on, thus can effectively avoid the student appraisal teaching subjectivity and the human feeling division. In scientific research, in addition to statistics on the number of scientific research results, big data can also monitor the progress of teachers' scientific research achievements, especially the supervision on the scientific research funds and effective evaluation of the value of scientific research achievements. These measures have important value for the evaluation of scientific research achievements. In other service work, big data can also set the corresponding indicators according to the teacher's position to collect the basic data, such as the class teacher's daily class management work and so on. Because big data has the openness to explore the inherent law of things, that is, the conclusion does not need to be preset in advance according to the fine data collected to study and analysis. Therefore, the big data based teacher performance management can make more unexpected evaluation and prediction based on these raw data.

\subsection{Convenient analytical means of data integration}

In the performance evaluation of college and university teachers, the determination and calculation of indicator weights is a cumbersome task, and the publicity and supervision of performance results are relatively complex. Through big data technology after the basic data collection and through the system cloud computing and big data analysis mining technology, we can make rapid and convenient data integration analysis and report errors on the abnormal data. In colleges and universities through the interconnection of big data, we can effectively integrate the data of all systems of the school, such as learning-worker system, one-card system, logistics service system. Even with teachers' personal websites, self-media platform systems can conduct data integration analysis. The utilization and analysis of these massive data resources can give full play to big data's characteristics. At the same time, with the accumulation of time and the continuous expansion of the underlying data, it can construct its own big data system library for each teacher, so that the performance management of teachers can be carried out more effectively.

\subsection{Personalized professional development based on big data early warning and evaluation}

Based on the support of big data analysis, data mining and other technologies, it can effectively evaluate and predict the law and direction of the development of things. In the performance management of university teachers based on big data, it can not only carry on the horizontal contrast analysis of each teacher's performance, but also carry on the longitudinal teacher's self-development appraisal in the time dimension. At the same time, it can model the performance of each teacher, so as to analyze and utilize the law of teacher performance, and can be real-time, effective early warning and evaluation for the development of teachers' performance, and then provide help for the development of teachers' professional ability. From the nature of performance management, the purpose of performance management is to promote the achievement of the work goal. Through the big data, the development of teacher's professional ability can further promote the promotion of the performance of the college and university. 


\section{The Innovative Path of College and University Teachers' Performance Management Based on Big Data}

\subsection{Collection and accumulation of basic data}

The collection and accumulation of raw data is an important prerequisite for big data's analysis. Therefore, in the long run, the implementation of teacher performance management needs a large amount of basic data accumulation and storage. The basic data of teachers mainly include personal basic information, teaching information, scientific research information, service information and so on. Among them, personal basic information can connect with the teaching system in colleges and universities, as well as teaching information, scientific research information and service information. Among them, the personal basic information can connect with the teaching staff system in colleges and universities. However, in the fields of teaching information, scientific research information and service information, the data collection in the past is mostly workload, and the collection of work results is very short of big data's analysis in the future, so we should set up more process indicators and collect and accumulate the raw data. From the point of view of acquisition means, card checking and attendance based on the one-card system is a relatively easy means to implement at present. At the same time, with the development of current technology, we can do the bottom data collection based on the campus network, such as monitoring the use of the teacher network and attendance analysis based on NFC location, etc. All of these can further implement the detailed collection of raw data, and this kind of "silent" data collection can avoid tedious manual operation and cause teachers' antipathy.

\subsection{Integration and management of information resources}

Compared with the traditional university system platform, the performance management platform based on big data needs to connect with several related systems in order to build and share the data, so the effective integration of information resources is the key link. At present, the scale and level of each university's network system are uneven, and the subsystems are relatively independent. Most of them are only the unified entry of employee accounts, but the sharing of contents and data is not enough. On the one hand, it is the lack of the function of the system construction itself. On the other hand, the suppliers of each system are mostly inconsistent, and the third party companies do not provide the data interface for the security of their own information. The relative opposition of this kind of system is a big obstacle to the later analysis of big data, so it is necessary to integrate and manage the information resources of each system step by step, especially on the past data integration, so that to further accelerate the development of performance management based on big data in colleges and universities.

\subsection{Gradual implementation of top-level design and input}

At present, teachers' performance management evaluation indicator is different; in addition, the content of evaluation is different to a large extent, because the performance management mechanism is not perfect and imperfect. With the further development of educational informatization, the application of big data in university teaching and management has become the focus. However, big data is difficult to operate independently for most colleges and universities. Therefore, top-level design and planning should be carried out at the government level, and investment should be implemented step by step. Of course, when it comes to implementation, it can be operated by a third party. However, the top-level planning and standard design need to be standardized by uniform industry standards in order to provide a basis for the sharing of information among colleges and universities in the future. However, the simple market behavior is very difficult to form in the short term the standard which accords with the university demand.

\subsection{Gradual improvement of teachers' informatization consciousness and ability}

Teachers are not only the subject of performance management, but also the object of performance management: As subjects, teachers are the makers and implementers of performance 
management rules. As an object, teachers are the objects of performance management in colleges and universities. This dual identity makes teachers play a key role in the intervention and application of new technologies, so the performance management based on big data requires teachers to have the awareness and ability of information, in order to effectively and steadily carry out the implementation. Of course, the development of technology will make the human-computer interaction become more and more natural and humanized, so the acquisition of big data's raw data will not lead to tedious manual operation to a certain extent. However, as a teacher, we should gradually understand big data, and then develop big data's application to promote the development of his own ability.

\section{Conclusions}

Aiming at the future performance management of college and university supported by big data, this study proposed four aspects of preparation works, including the collection and accumulation of basic data, the integrated management of information resources, and the top-level design, the gradual implementation of investment and the gradual improvement of teachers' informatization awareness and ability in order to provide reference for the future university based on big data's teacher performance management.

\section{References}

[1] Zhu Zhu. Reflections on the Performance Management of Colleges and Universities under the Background of Big Data [J]. Proceedings of the China Journal of Multimedia and Network Teaching (Electronic Edition), 2017, (04): 237.

[2] Deng Yadang. A study on the Performance Evaluation of Government in Big Data's Era [D]. Party School of Guangdong Provincial Party Committee of the Communist Party of China, 2017.

[3] Zhao Yiming, Hao Jianjiang. Enlightenment of Big Data's Thinking to the Performance Management of College and University Teachers [J]. China's Educational Informatization, 2017, (05): 1-3.

[4] Cheng Ping, Zhao Jinglan. Performance Management of Financial Sharing Center in the Era of Big Data Based on Cloud Accounting [J]. Friends of Accounting, 2017, (04): 130-133.

[5] Han Jinfeng. Analysis on the Innovation of Enterprise Human Resource performance Management in Big Data Era [J]. Human Resources Management, 2016, (08): 11-12.

[6] Xu Yan. Innovation of Enterprise Human Resource Performance Management in Big Data Era [J]. Jiangxi Social Science, 2016, (02): 182-187.

[7] Wang Yandan. Performance Management in the Era of Big Data [J]. Business and Management, 2015, (12): 56-58. 